\title{
Rhaponticin as an anti-inflammatory component of rhubarb: a minireview of the current state of the art and prospects for future research
}

\author{
Joanna Kolodziejczyk-Czepas (iD) Jan Czepas
}

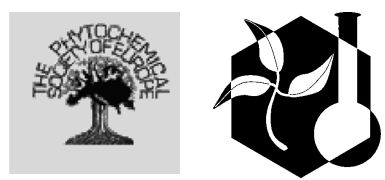

Received: 3 July 2019/ Accepted: 23 September 2019/Published online: 28 September 2019

(C) The Author(s) 2019

\begin{abstract}
Rhaponticin
$\left(3,3^{\prime}, 5\right.$-trihydroxy-4'methoxystilbene 3-O- $\beta$-D-glucoside; synonymrhapontin), is a stilbene compound, mainly found in various species of rhubarb (Rheum L.). The aglycone, rhapontigenin, is thought to be the biologically active form of rhaponticin. As a component of rhubarb, rhaponticin may be present in the human diet both in foods and dietary supplements. Although promising reports have been published on the various activities of rhaponticin (see: antioxidant, estrogenic, antithrombotic, anticancer and anti-inflammatory actions), no comprehensive review exists of its anti-inflammatory properties. Therefore, the aim of the present work is to summarize the existing evidence of the anti-inflammatory properties of rhaponticin and provide a prospective insight into research on this stilbenoid.
\end{abstract}

Keywords Rhaponticin - Rhapontin ·

Rhapontigenin $\cdot$ Rhubarb · Anti-inflammatory

J. Kolodziejczyk-Czepas ( $\square)$

Department of General Biochemistry, Faculty of Biology and Environmental Protection, University of Lodz,

Pomorska 141/143, 90-236 Lodz, Poland

e-mail: joanna.kolodziejczyk@biol.uni.lodz.pl

\section{J. Czepas}

Department of Molecular Biophysics, Faculty of Biology and Environmental Protection, University of Lodz, Lodz, Poland

\section{Introduction}

The antioxidant properties of natural, plant-derived substances are widely believed to be of primary importance in the prevention of civilization diseases. The latest decade has provided new insights into the multifactorial pathophysiology of these disorders, and with them, some dose of criticism regarding the principal role played by the antioxidant activity of plant-derived compounds. The health-promoting and disease-preventive effects of antioxidants, observable at the level of the whole organism, may result from diverse molecular pathways, including not only reactions with oxidants, but also the ability to regulate gene transcription and modulate the adaptive response. The beneficial effects of many natural antioxidants and chemopreventive agents are also dependent on their anti-inflammatory actions (see Goszcz et al. 2015; Leopold 2015; Pashkow 2011). Disease-associated inflammation forms a complex network of interactions between pro-inflammatory mediators, oxidative stress and host immune response, as well as pathological changes in the physiology of organs and tissues. It is involved both in the pathogenesis and pathophysiology of numerous disorders, including malignant transformation and tumour progression, as well as the development of cardiovascular diseases and their complications (see Chang and Yang 2016; Moriya 2019; Yao and Narumiya 2019). For that reason, the anti-inflammatory activity of plant-derived 
substances is a highly desirable biological property, widely regarded as being crucial for maintaining human health.

Rhaponticin (3,3',5-trihydroxy-4'-methoxystilbene $3-O-\beta$-D-glucoside; synonym-rhapontin) is a stilbenetype compound found in the human diet; its aglycone form is rhapontigenin (Fig. 1). The stilbenoids are a well-known group of bioactive phytochemicals, that are synthesized by various plant species and accumulated in aerial and underground plant organs. Although resveratrol still remains the best described stilbene (see Cheng et al. 2019; Ramírez-Garza et al. 2018), it should be noted that this class of polyphenols includes many other bioactive compounds, such as rhapontigenin and rhaponticin, which display a wide range of beneficial activities, including antioxidant, estrogenic, antithrombotic, anticancer and anti-inflammatory effects (see Czop et al. 2019; Kim and Ma 2018; Park et al. 2002; Sun et al. 2017; Wober et al. 2007; Zhang et al. 2007).

This short review summarizes the current literature concerning the anti-inflammatory activities of rhaponticin and its aglycone, and provides a prospective insight into research on these phytochemicals. The records were identified by a search of the PubMed/ Medline, Science Direct, Springer Link, Google Scholar and Scopus databases (until June, 2019). Although recent years have provided a wealth of novel data on research trends and the bioactivity of rhaponticin and rhapontigenin, as with many other polyphenols, this research has not only yielded very promising results, but it has also revealed hitherto poorlyrecognized aspects of its biological activity.

\section{Sources of rhaponticin and its content in plant- derived preparations}

Originally, rhaponticin was identified in Rheum rhaponticum L. (rhapontic rhubarb), and to date, it has been primarily listed as one of the most important bioactive substances of various rhubarb species. Its structural characteristics and chemical properties are summarized in a recent paper by Sun et al. (2017).<smiles>[R10]CCCC[R12]([H])([H])C=Cc1cc(O)cc(O)c1</smiles>

Fig. 1 Structures of rhaponticin $\left(3,3^{\prime}, 5\right.$-trihydroxy- $4^{\prime}$-methoxystilbene 3-O- $\beta$-D-glucoside; IUPAC name: $(2 \mathrm{~S}, 3 \mathrm{R}, 4 \mathrm{~S}, 5 \mathrm{~S}, 6 \mathrm{R})-2-$ [3-hydroxy-5-[(E)-2-(3-hydroxy-4-methoxyphenyl)ethenyl]phenoxy]-6-(hydroxymethyl)oxane-3,4,5-triol) and its aglycone, rhapontigenin (IUPAC name: 5-[(E)-2-(3-hydroxy-4-methoxy phenyl)ethenyl]benzene-1,3-diol) 
Quantitative analyses of rhaponticin content in plants include various advanced techniques such as ultraperformance liquid chromatography-diode array detection (UPLC-DAD), high-speed counter-current chromatography (HSCCC), $\beta$-cyclodextrin-modified micellar electrokinetic chromatography (CD-MEKC), zone electrophoresis with diode array detector (CZE$\mathrm{DAD}), \mathrm{Fe}_{3} \mathrm{O}_{4}$-based magnetic molecularly imprinted polymers (MMIPs) (Sun et al. 2017) as well as thinlayer chromatography (TLC) (Smolarz et al. 2013).

The rhaponticin content in Rheum species varies significantly depending on the type of the plant material and the mode of extraction, up to about $55 \mathrm{mg} / \mathrm{g}$ of dry weight (Table 1). A recent study employing a response surface methodology to improve the plant material extraction process, developed an optimal procedure based on the use of $57 \%$ EtOH, at $65{ }^{\circ} \mathrm{C}$, for $24 \mathrm{~h}$. This protocol yielded rhaponticin content of $13.17 \%$ in extract of $R$. undulatum roots (Kwak et al. 2019). Rhaponticin was also detected in other plants such as Trigonella foenum-graecum L. (fenugreek) (He et al. 2016; Li et al. 2018), Guibourtia tessmannii (Harms) J. Leonard (Nyemba et al. 1995), Stuhlmannia moavi Taub. (Liu et al. 2013), Eucalyptus rubida H. Deane \& Maiden (Etoh et al. 1990) and Baccharis grisebachii Hieron (Gómez et al. 2019).
So far, the literature has provided very few reports dealing with quantitative estimation of rhaponticin and rhapontigenin in foods. Most works on the phytochemical profiling of dietary products contain a collective quantification of stilbene-type compounds and their derivatives or provide data on stilbenes other than rhapontigenin (mainly resveratrol). The total concentration of stilbene-type compounds in different wines (considered to be their most abundant source), can be as high as several $\mathrm{mg} / \mathrm{L}$ of a product (El Khawand et al. 2018). Depending on the maceration times, trans-resveratrol and trans-piceid concentrations in wines were found to reach up to 1.75 and $4.48 \mathrm{mg} / \mathrm{L}$, respectively (Kostadinović et al. 2012). In fresh wine grape skins, the resveratrol content may range from 19 to $508 \mu \mathrm{g} / \mathrm{g}$, and that of trans-piceid could be as high as $196 \mu \mathrm{g} / \mathrm{g}$ (Vincenzi et al. 2013). Studies of edible berries found resveratrol to be present at levels up to $15.72 \mu \mathrm{g} / \mathrm{g}$ of fresh weight (f.w.) in red currant (Ribes rubrum L.), $19.29 \mu \mathrm{g} / \mathrm{g}$ f.w. in cranberry (Vaccinium oxycoccos L.) and $30 \mu \mathrm{g} / \mathrm{g}$ f.w. in cowberry (Vaccinium vitis-idaea L.) (Błaszczyk et al. 2019). In cocoa powders, the trans-resveratrol content was $1.85 \pm 0.43 \mu \mathrm{g} / \mathrm{g}$, and the trans-piceid content $7.14 \pm 0.80 \mu \mathrm{g} / \mathrm{g}$ (Hurst et al. 2008). Isorhapontigenin was not detected in wine, but was found to be present at levels ranging from 0.55 to

Table 1 Exemplary data on rhaponticin content in different Rheum species

\begin{tabular}{|c|c|c|}
\hline Rhubarb species & Rhaponticin content and the extraction mode & References \\
\hline $\begin{array}{l}\text { R. franzenbachii } \\
\text { Münter }\end{array}$ & $\begin{array}{l}1.59 \pm 0.077 \mathrm{mg} / \mathrm{g} \text { of dried leaves (extracted with } 80 \% \mathrm{EtOH} \text {, for } 2 \mathrm{~h} \text { ) } \\
4.36 \pm 0.135 \mathrm{mg} / \mathrm{g} \text { of dried roots (extracted with } 80 \% \mathrm{EtOH} \text {, for } 2 \mathrm{~h} \text { ) }\end{array}$ & $\begin{array}{l}\text { Wang et al. } \\
\text { (2014) }\end{array}$ \\
\hline $\begin{array}{l}\text { R. rhaponticum } \\
\text { L. }\end{array}$ & $\begin{array}{l}38.07-40.83 \mathrm{mg} / \mathrm{g} \text { of dried roots (in plant material collected from April till October), while the } \\
\text { rhapontigenin content varied from } 1.4 \text { to } 1.62 \mathrm{mg} / \mathrm{g} \text { of dried roots (plant material macerated } \\
\text { with } 100 \% \text { methanol, for } 72 \mathrm{~h} \text { ) } \\
25.5 \pm 0.4 \mathrm{mg} / \mathrm{g} \text { of dried roots (extracted with the boiled } 80 \% \text { methanol solution for } 1 \mathrm{~h} \text { ) } \\
0.3 \pm 0.09 \mathrm{mg} / \mathrm{g} \text { of dried petioles (extracted with the boiled } 80 \% \text { methanol solution for } 1 \mathrm{~h} \text { ) }\end{array}$ & $\begin{array}{l}\text { Smolarz et al. } \\
(2013)\end{array}$ \\
\hline $\begin{array}{l}\text { R. tanguticum } \\
\text { Maxim. }\end{array}$ & $\begin{array}{l}25.5 \mathrm{mg} \text { of trans-rhaponticin and } 16.0 \mathrm{mg} \text { of } \mathrm{cis} \text {-rhaponticin were isolated from } 80 \mathrm{mg} \text { of crude } \\
\text { sample (extracted from dried roots, using } 70 \% \text { ethanol under reflux, three times, each one for } \\
2 \mathrm{~h} \text { ) }\end{array}$ & $\begin{array}{l}\text { Zhao et al. } \\
\text { (2013) }\end{array}$ \\
\hline R. undulatum $\mathrm{L}$. & $\begin{array}{l}31.5 \pm 3.8 \mathrm{mg} / \mathrm{g} \text { of dried roots (extracted with the boiled } 80 \% \text { methanol solution for } 1 \mathrm{~h} \text { ) } \\
0.8 \pm 0.1 \mathrm{mg} / \mathrm{g} \text { of dried petioles (extracted with the boiled } 80 \% \text { methanol solution for } 1 \mathrm{~h} \text { ) } \\
54.54 \pm 24.59 \mathrm{mg} / \mathrm{g} \text { of dried rhizome (ultrasonic extraction with } 70 \% \text { ethanol for } 1 \mathrm{~h} \text { ) }\end{array}$ & $\begin{array}{l}\text { Smolarz et al. } \\
\quad(2013) \\
\text { VanMen et al. } \\
\text { (2012) }\end{array}$ \\
\hline & $\begin{array}{l}2.9 \mathrm{mg} / 100 \mathrm{mg} \text { of the } 100 \% \mathrm{EtOH} \text { root extract (isolated at } 60{ }^{\circ} \mathrm{C} \text {, for } 24 \mathrm{~h} \text { ) } \\
14.66 / 100 \mathrm{mg} \text { of the } 50 \% \mathrm{EtOH} \text { root extract (isolated at } 100{ }^{\circ} \mathrm{C} \text {, for } 24 \mathrm{~h} \text { ) } \\
15.44 / 100 \mathrm{mg} \text { of the } 50 \% \mathrm{EtOH} \text { root extract (isolated at } 60^{\circ} \mathrm{C} \text {, for } 13 \mathrm{~h} \text { ) }\end{array}$ & $\begin{array}{l}\text { Lee et al. } \\
\quad(2018)\end{array}$ \\
\hline
\end{tabular}


$1.28 \mathrm{mg} / \mathrm{kg}$ f.w. in grape pomace (Fernández-Marín et al. 2014).

More detailed information on rhaponticin and rhapontigenin contents can be derived from studies on herbal material originating from rhubarb (Table 1). For instance, rhaponticin and rhapontigenin content in $R$. rhaponticum roots collected from April to October was found to demonstrate moderate variability depending on the plant growth stage. The total amount ranged from 36.48 to $43.20 \mathrm{mg} / \mathrm{g}$ of air-dried root for rhaponticin, and from 1.17 to $1.62 \mathrm{mg} / \mathrm{g}$ for rhapontigenin. In contrast, the content of resveratrol was more variable, ranging from $0.15 \mathrm{mg} / \mathrm{g}$ of air-dried root (in April) to $4.99 \mathrm{mg} / \mathrm{g}$ (in October) (Aaviksaar et al. 2003).

Studies on effects of different cooking regimes on the polyphenol content in rhubarb ( $R$. rhaponticum) petioles found fast stewing, slow stewing and baking, to enhance both the total content of polyphenolic compounds and overall antioxidant capacity of the examined samples, compared to raw petioles; no such effect was observed for blanching. The highest polyphenolic content (in the filtrate of the homogenized pulp) was obtained by slow cooking for $30 \mathrm{~min}$ and baking for $20 \mathrm{~min}$. This increase in polyphenolic content was most likely a result of thermal degradation of plant material and the ensuing release of these substances from plant cells and tissues (McDougall et al. 2010). However, no such information exists on changes in rhaponticin and rhapontigenin contents in rhubarb-containing foods or other dietary products, and as such, the above-mentioned results may constitute a basis for further studies, involving the quantitative analysis of stilbene content, especially rhaponticin and rhapontigenin, in rhubarb during thermal processing at low and high temperatures.

Besides rhubarb-containing foods, rhaponticin is a component of dietary supplements or herbal medicines, mainly recommended to alleviate menopausal complaints. The content of $R$. rhaponticum extract in such preparations usually ranges from 4 to $1000 \mathrm{mg}$; however, detailed information on the rhaponticin contents in plant extracts is not always available. According to data given by manufacturers, herbal medicines and dietary supplements typically provide milligram doses of rhaponticin: e.g. a preparation providing $4 \mathrm{mg}$ of $R$. rhaponticum extract (ERr $\left.731^{\circledR}\right)$ / one tablet contains $2.2 \mathrm{mg}$ of rhaponticin, another product contains $150 \mathrm{mg}$ of rhubarb extract in one capsule (incl. $0.77 \%$ of rhaponticin), while a rhubarbbased dietary supplement provides $4 \mathrm{mg}$ of $R$. rhaponticum extract per one tablet, standardized to $\geq 54 \%$ of rhaponticin.

\section{Anti-inflammatory action of rhaponticin and rhapontigenin}

In vitro data

Available evidence suggests that rhaponticin and rhapontigenin have moderate inhibitory effects on key enzymes of the arachidonic acid cascade (Table 2). In addition, these compounds not only inhibit COXs but also hyaluronidase (HYAL), belonging to another class of pro-inflammatory enzymes (Kim et al. 2000). Although both of the abovementioned compounds were found to inhibit the cyclooxygenase enzyme isoforms 1 (COX-1) and 2 (COX-2) or lipoxygenase (LOX), in most cases their efficiency was weaker than that of resveratrol $\left(3,4^{\prime}, 5\right.$ trihydroxy-trans-stilbene) (Kutil et al. 2015; Ngoc et al. 2008; Park et al. 2016; Shin et al. 1998). Moreover, the fact that resveratrol and other applied reference substances are non-selective COX inhibitors significantly hinders reliable evaluation of the inhibitory potential of rhaponticin or rhapontigenin.

While rhapontigenin (the metabolite) is the active constituent of rhaponticin, the latter form (glycoside) evidently has lower activity. In a work of Kim et al. (2000), rhaponticin isolated from the rhizomes of $R$. undulatum was even designated as a prodrug-a source of the biologically active metabolite. Yamamoto et al. (2017) demonstrated that the nitric oxide (NO) production in macrophages declined by $34 \%$ upon treatment with rhapontigenin $(30 \mu \mathrm{M})$, compared to only $23 \%$ inhibition by resveratrol. Elsewhere, NO production in macrophages was found to be partly decreased by both rhaponticin $\left(\mathrm{IC}_{50-}\right.$ $<100 \mu \mathrm{M}$ ) and rhapontigenin $\left(\mathrm{IC}_{50}=48 \mu \mathrm{M}\right)$, but more effective inhibition was observed for their naturally-occurring gallates, i.e. rhaponticin $2^{\prime \prime}-O$ gallate and rhaponticin $6 "$ - $O$-gallate $\left(\mathrm{IC}_{50}=13\right.$ and $11 \mu \mathrm{M}$, respectively) (Kageura et al. 2001; Matsuda et al. 2000). Although neither rhaponticin nor rhapontigenin inhibited the activity of inducible nitric oxide synthase (iNOS) in the above-mentioned experiments, 
Table 2 Inhibitory properties of rhaponticin and rhapontigenin towards pro-inflammatory enzymes in comparison to reference compounds

\begin{tabular}{llll}
\hline $\begin{array}{l}\text { The examined } \\
\text { enzyme }\end{array}$ & $\begin{array}{l}\mathrm{IC}_{50} \text { established for rhapontigenin and } \\
\text { rhaponticin }\end{array}$ & $\begin{array}{l}\mathrm{IC}_{50} \text { established for reference } \\
\text { compounds }\end{array}$ & References \\
\hline COX-1 & $\begin{array}{l}58 \mu \mathrm{M} \text { (rhapontigenin) } \\
\text { (rhaponticin) }\end{array}$ & $24 \mu \mathrm{M}$ (resveratrol) & Shin et al. (1998) \\
& $24.6 \mu \mathrm{M}$ (rhapontigenin) & $2 \mu \mathrm{M}$ (indomethacin) & Kutil et al. (2015) \\
COX-2 & $36.1 \mu \mathrm{M}$ (rhapontigenin) & $3.4 \mu \mathrm{M}$ (resveratrol) & Kutil et al. (2015) \\
LOX & 10.7 (rhapontigenin) & $3.4 \mu \mathrm{M}$ (baicalein) & (2016) \\
& $34.3 \mu \mathrm{M}$ (rhaponticin) & $19.7 \mu \mathrm{M}$ [(+)-catechin] & Kutil et al. (2015) \\
& & $12.3 \mu \mathrm{M}$ (resveratrol) & Kim et al. (2000) \\
HYAL & $>50 \mu \mathrm{M}$ (rhapontigenin) & $15.2 \mathrm{mM}$ (sodium cromoglycate) & \\
\end{tabular}

both compounds effectively inhibited iNOS expression in the investigated macrophages.

Some insight into the molecular basis of the antiinflammatory actions of rhaponticin and rhapontigenin has been provided by cellular experimental systems (Fig. 2). However, due to the limited extent of in vitro studies and the substantial variation between studies with regard to experimental settings and conditions, the pharmacological significance of the anti-inflammatory actions of rhapontigenin and rhaponticin is still difficult to estimate. In addition, only the small number of reported results exists regarding reference anti-inflammatory clinically used drugs such as indomethacin. Most studies of the activities of rhaponticin and rhapontigenin compare them to resveratrol or other polyphenolics (Table 2). Hence, more detailed and advanced studies, including a variety of reference drugs and standardized experimental settings are needed to evaluate the safety of rhaponticin and rhapontigenin and their inhibitory efficiency towards inflammatory processes.

Despite sharing some biochemical pathways and molecular targets, the physiological effects of rhaponticin and rhapontigenin still remain poorly understood, when compared to the current knowledge of biological actions of resveratrol. Accumulating evidence from in vitro and in vivo investigations has indicated that resveratrol displays a wide range of beneficial properties such as antioxidant, cardioprotective, anticancer, neuroprotective and anti-inflammatory action (see Cheng et al. 2019; Ramírez-Garza et al. 2018). Resveratrol may interact with different targets and modulate the activities of numerous pro-inflammatory mediators through the inhibition of the nuclear factor kappa B (NF- $\mathrm{B}$ ) activation, reduction of inflammatory cytokine levels and iNOS activity as well as
Fig. 2 Possible mechanisms of antiinflammatory actions of rhaponticin and rhapontigenin

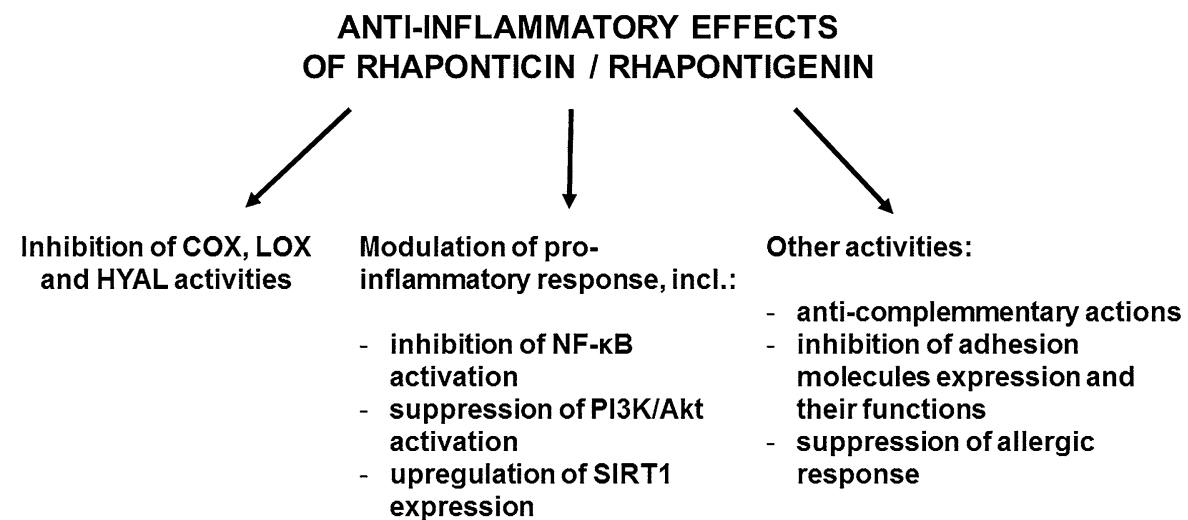


regulation of cell adhesion molecules and sirtuin 1 (SIRT1) expression (de Sá Coutinho et al. 2018). Similarly to resveratrol, the anti-inflammatory action of rhaponticin and rhapontigenin also involves the inhibition of the activation of NF- $\mathrm{KB}$. Structureactivity relationship (SAR) studies indicated that the oxygen-containing functional groups such as $-\mathrm{OH}$ and $-\mathrm{OCH}_{3}$ in the benzene ring might be essential for the activity of rhaponticin and rhapontigenin. The presence of a glucose moiety reduced this anti-inflammatory activity, while the $\alpha$-, $\beta$-double bond had no effect (Kageura et al. 2001). Experiments on human myeloid cells confirmed the significance of hydroxyl groups for the anti-inflammatory activity of stilbenoids; however, the glycoside form (rhaponticin) was not found to have any inhibitory effect on NF- $\mathrm{BB}$ activation (Ashikawa et al. 2002). A recent study by Eräsalo et al. (2018) revealed that several aglycone stilbenoids (i.e. pinosylvin, monomethylpinosylvin, resveratrol, pterostilbene, piceatannol and rhapontigenin) have inhibitory effects on the pro-inflammatory response of macrophages. Simultaneously, it has also been found that the glycosides (astringin and rhaponticin) had weaker activity than their non-glycosylated forms (Eräsalo et al. 2018). Molecular pathways of anti-inflammatory actions of the examined stilbenoid aglycones have been shown to involve the suppression of PI3K/Akt activation. Furthermore, it has been suggested that the anticancer activity of rhapontigenin within the inflammatory microenvironment of a tumour may be based on the inhibition of TGF- $\beta$-mediated epithelial-mesenchymal transition depending on the PI3K/Akt/ mTOR pathway (Yeh et al. 2016). Additionally, rhapontigenin was found to upregulate the expression of SIRT1 in the THP-1 human monocytic cell line (Kawakami et al. 2014). Since SIRT1 acts as an inhibitor of NF- $\kappa$ B activation (via deacetylation of the p65 subunit) (see Kauppinen et al. 2013), low activity of SIRT1 or its inhibition in cells results in an inflammatory response, triggered by the NF- $\kappa \mathrm{B}-$ dependent activation of genes for cytokines such as tumour necrosis factor alpha (TNF- $\alpha$ ) and interleukin6 (IL-6). Conversely, compounds increasing SIRT1 level (such as rhapontigenin) might reduce the inflammatory response.

Other available evidence of biological activities of rhapontigenin possibly related to its anti-inflammatory properties includes anti-adhesive, immunomodulatory and anti-allergic effects (briefly summarized in Table 3).

Bioavailability of rhaponticin and limitations of its potential pharmacological use

Like many other polyphenols, rhaponticin and rhapontigenin also exist both in cis and trans isoforms in plant species and are photosensitive compounds (Fig. 3). Although the trans forms are primarily responsible for the biological actions of these compounds, susceptibility to UV-induced isomerization may result in their undesirable conversion into the less active cis form, leading to a significant decrease of bioactivity. Such isoforms have been identified in biological samples by analyses of the cis-trans isomerization kinetics of stilbenes, for example, by capillary electrophoresis and spectroscopic methods (Hui et al. 2011). This concept could be useful in evaluating of the content of photosensitive compounds, especially in the context of controlling the presence and stability of the biologically-active trans isomers in biological samples.

The pharmacokinetics of rhaponticin/rhapontigenin has been examined using various techniques, including UHPLC-Q-TOF/MS, UHPLC-DAD-MSn (Zhao et al. 2012), or analysis after complexation with cerium $\left(\mathrm{Ce}^{3+}\right)$ (Sun et al. 2013) and erbium $\left(\mathrm{Er}^{3+}\right)$ (Sun et al. 2016) ions. Since the metabolism of rhaponticin has recently been extensively discussed by Chen et al. (2019), these issues are only briefly mentioned here. Rhaponticin is quickly metabolized and distributed in vivo; its absolute bioavailability after oral administration was found to be $0.03 \%$ (Zhao et al. 2012). Molecular modelling of human serum albumin (HSA)-rhaponticin interactions demonstrated that rhaponticin binds to the sub-domain IIA hydrophobic cavity (site I) of HSA (Sun et al. 2012). The HSA protein binding rate $(\%)$ for rhapontigenin has recently been estimated as $79.99 \pm 0.59 \%$ (Cao et al. 2019). The concentration of rhapontigenin in blood plasma declines rapidly: after an intravenous dose of $10 \mathrm{mg} / \mathrm{kg}$ of body weight (b.w.), its half-life in rat plasma was found to be $3.0 \pm 1.35 \mathrm{~h}$ with a volume of distribution of $11.05 \mathrm{~L} \mathrm{~kg}^{-1}$. The total plasma clearance and hepatic clearance of rhapontigenin were $1.18 \mathrm{~L} \mathrm{~h}^{-1} \mathrm{~kg}^{-1}$ and $1.165 \mathrm{~L} \mathrm{~h}^{-1} \mathrm{~kg}^{-1}$, respectively. The mean area under the curve (AUC) was estimated to be $8.39 \mu \mathrm{g} \mathrm{h} \mathrm{mL}^{-1}$ (Roupe et al. 2006). Rhaponticin has also been found to undergo 
Table 3 Broader insight into anti-inflammatory properties of rhapontigenin and rhaponticin—brief data on other evidence that may be related to their anti-inflammatory actions

\begin{tabular}{|c|c|c|}
\hline Experimental system & Main findings & References \\
\hline Complement activation in vitro & $\begin{array}{l}\text { Anti-complementary actions of rhapontigenin and } \\
\text { rhaponticin }\left(\mathrm{IC}_{50}=370 \mu \mathrm{M} \text { and } 700 \mu \mathrm{M} \text {, respectively) }\right. \\
\text { in classical pathway }\end{array}$ & $\begin{array}{l}\text { Oh et al. } \\
\text { (1998) }\end{array}$ \\
\hline $\begin{array}{l}\text { Human monocytic cell line THP1 (cells stimulated by } \\
\text { TNF- } \alpha \text { ) }\end{array}$ & $\begin{array}{l}\text { Moderate inhibitory effect of rhapontigenin on the } \\
\text { expression of intercellular adhesion molecule-1 (ICAM- } \\
\text { 1) on THP1 cells; no effects for rhaponticin were found }\end{array}$ & $\begin{array}{l}\text { Ahn et al. } \\
\text { (2000) }\end{array}$ \\
\hline $\begin{array}{l}\text { Rat peritoneal exudate cells, stimulated by the } \\
\text { compound } 48 / 80 \text { or calcium ionophore A-23-187 }\end{array}$ & $\begin{array}{l}\text { In the compound } 48 / 80 \text { experiments: reduction of } \\
\text { histamine release, with } \mathrm{IC}_{50} \text { of } 0.29 \mu \mathrm{M} \text { and } 0.079 \mathrm{nM} \text {, } \\
\text { for rhaponticin and rhapontigenin, respectively } \\
\text { In the calcium ionophore } \mathrm{A}-23-187 \text { experiments: reduction } \\
\text { of histamine release, with } \mathrm{IC}_{50} \text { of } 0.90 \mu \mathrm{M} \text { and } 0.25 \mathrm{nM} \text {, } \\
\text { for rhaponticin and rhapontigenin, respectively }\end{array}$ & $\begin{array}{l}\text { Kim et al. } \\
(2000)\end{array}$ \\
\hline Chinese hamster lung fibroblasts (V79-4) & $\begin{array}{l}\text { Inhibition of the activity of activator protein } 1 \text { (AP-1) } \\
\text { transcription factor by rhapontigenin }\end{array}$ & $\begin{array}{l}\text { Zhang et al. } \\
\text { (2007) }\end{array}$ \\
\hline THP1 cells & $\begin{array}{l}\text { Inhibitory effects of rhapontigenin on direct binding } \\
\text { between sICAM-1 and the lymphocyte function- } \\
\text { associated antigen-1 (LFA-1) on the examined cells } \\
\left(\mathrm{IC}_{50}=25.4 \mu \mathrm{M}\right) \text {; moderate inhibition ( } 46 \% \text { at a conc. of } \\
100 \mu \mathrm{M}) \text { of the VLA- } 4 \text { antigen of THP-1 cells and the } \\
\text { vascular cell adhesion molecule (sVCAM-1) }\end{array}$ & $\begin{array}{l}\text { Lee et al. } \\
\text { (2012) }\end{array}$ \\
\hline $\begin{array}{l}\text { Antigen-stimulated rat basophilic leukaemia cells } \\
\text { (RBL-2H3 cells) }\end{array}$ & $\begin{array}{l}\text { Anti-allergic properties of rhapontigenin, i.e. inhibition of } \\
\text { cell degranulation, measured as the antigen-induced } \\
\text { release of } \beta \text {-hexosaminidase from RBL-2H3 cells } \\
\left(\mathrm{IC}_{50}=14 \mu \mathrm{M}\right)\end{array}$ & $\begin{array}{l}\text { Matsuda } \\
\text { et al. } \\
(2016)\end{array}$ \\
\hline
\end{tabular}<smiles>[R]Oc1cc(O)cc(/C=C/c2ccc(OC)c(O)c2)c1</smiles>

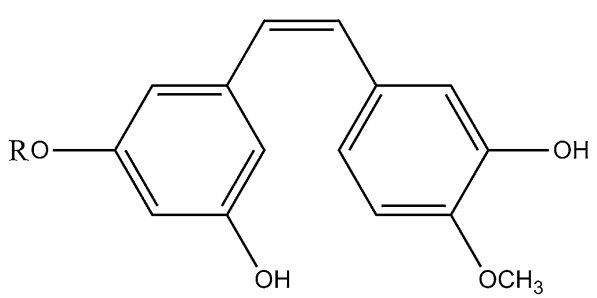

R-H cis-rhapontigenin R-Gle cis-rhaponticin

Fig. 3 The UV-induced cis-trans isomerization of rhaponticin and rhapontigenin (mechanism proposed by Hui et al. 2011)

rapid distribution and elimination from plasma. Pharmacokinetic analyses performed in a murine model following an oral dose of $100 \mathrm{mg} / \mathrm{kg}$ b.w. or injection with $10 \mathrm{mg} / \mathrm{kg}$ b.w. into the caudal vein revealed the presence of rhapontigenin in blood plasma 5 min after the injection, and its maximal concentration was $8.91 \mu \mathrm{g} \mathrm{mL}^{-1}$. Oral administration of rhaponticin provided lower blood plasma concentrations of its metabolite with the maximal concentration of $1.71 \mu \mathrm{g} \mathrm{mL}^{-1}$. The total clearance values for intravenous and oral administration of rhaponticin were 0.047 and $18.7 \mathrm{~mL} \mathrm{~min}^{-1} \mathrm{~kg}^{-1}$, respectively, whereas their $\mathrm{AUC}_{(0-\mathrm{t})}$ was $215.8 \mu \mathrm{g} \min \mathrm{mL}^{-1}$ and $0.70 \mu \mathrm{g}$ min $\mathrm{mL}^{-1}$ (Zhao et al. 2011, 2012).

The poor solubility of rhaponticin in an aqueous environment and its fast metabolism have been listed 
as the main factors limiting further studies on its pharmacological actions. While several clinical examinations on rhubarb-based preparations have been registered, with 14 trials being recorded until June 2019 in the ClinicalTrials.gov NIH database (https:// clinicaltrials.gov), no clinical trial has yet been performed on rhaponticin. Promising data suggests that both rhaponticin and rhapontigenin may possess considerable health-promoting or pharmacological potential; these findings may contribute to the development of new modes of drug delivery and accelerate pharmacological studies on these compounds. Therefore, some attempts have been undertaken in order to improve the bioavailability of rhaponticin. One of these strategies may be a construction of PEGylated liposomes containing rhaponticin (PEGL-RA). Preliminary tests suggested that these particles were effective delivery vehicles for rhaponticin, with a $T_{\max }$ approximately 4.5 times higher than that of rhaponticin alone. In addition, rhaponticin displayed a higher mean $\mathrm{T}_{1 / 2}$ value $(350.12 \mathrm{~min}$ ) when delivered in PEGylated liposomes than alone (i.e. $180.02 \mathrm{~min}$ ) (Sun and Zhao 2012).

Another way of improvement of rhaponticin bioavailability can be the synthesis of a folate receptor-targeted rhaponticin conjugate (Liang et al. 2013). This water-soluble conjugate was developed using a hydrophilic peptide spacer, linked to folic acid by a releasable disulfide linker, providing an aminoreactive derivative of rhaponticin. Although preliminary in vitro and in vivo examinations suggest that this formulation of rhaponticin may have considerable potential, especially as a chemotherapeutic agent, no further results have yet been published. In other examinations, rhaponticin was incorporated into phosphatidylcholine (PC-Chol) liposomes, designed for the delivery of cyclodextrin-bound drugs (Lim et al. 2008). The passage of PC-Chol liposomes with complexes of rhaponticin and $\beta$-cyclodextrin (HP $\beta C D-R h 2$ complexes) through guinea pig skin has also been established in preliminary studies.

In vivo evidence

So far, anti-inflammatory actions of rhaponticin and rhapontigenin have been evidenced in vivo in rodents (Table 4). Rhaponticin significantly reduced the development and expansion of pathological changes in an in vitro model of experimental pulmonary fibrosis, as well as in the bleomycin-induced pulmonary fibrosis in mice treated with daily doses of $25 \mathrm{mg}$ and $100 \mathrm{mg} / \mathrm{kg}$ b.w. (Tao et al. 2017). At a daily dose of $100 \mathrm{mg} / \mathrm{kg}$ b.w., rhaponticin was also found to reduce colonic epithelial dysfunction in a mouse experimental model of colitis; the action involved SIRT1-dependent signalling (Wei et al. 2017). In other work, 50 and $100 \mathrm{mg} / \mathrm{kg}$ b.w. of rhapontigenin and $100 \mathrm{mg} / \mathrm{kg}$ b.w. of rhaponticin displayed anti-inflammatory effects in rats with carrageenan-induced edema (Ko et al. 2004). In mice, rhapontigenin (25 $\mathrm{mg}$ and $50 \mathrm{mg} / \mathrm{kg}$ b.w.) demonstrated greater anti-inflammatory and anti-allergic effects than disodium cromoglycate, an anti-allergic drug (100 mg/kg b.w.), in the treatment of passive cutaneous anaphylaxis (PCA) reaction. Similar results were obtained for analogous experiments conducted on rats, and complemented with in vitro studies on the anti-thrombotic effects of rhaponticin and rhapontigenin (Park et al. 2002). It has been suggested that such anti-inflammatory activity of rhapontigenin may constitute an important mechanism involved in its cardioprotective effect. In a murine model of isoproterenol-induced myocardial infarction, treatment with rhapontigenin $\quad(5.0 \mathrm{mg} / \mathrm{kg} \quad$ b.w./day $)$ ameliorated pathological changes in the heart and downregulated the expression of TNF- $\alpha$, IL-6, p38 mitogen-activated protein kinase and iNOS in the examined animals (Fan 2019).

\section{Conclusions}

The currently available literature confirms that rhaponticin displays anti-inflammatory properties, which may enhance its health-promoting actions or pharmacological potential. However, most of this evidence is still derived from basic studies. Despite promising data from in vitro investigations, only six animal studies examining the anti-inflammatory action of rhaponticin have been described so far. When compared to resveratrol, the physiological effects and pharmacological significance of rhapontigenin still remain underestimated. As a promising natural medicine, resveratrol has been intensively examined, with over 120 clinical studies currently registered in the www.clinicaltrials.gov database. While the anti-inflammatory effects of resveratrol have been established in numerous in vitro and in vivo 
Table 4 In vivo evidence of anti-inflammatory activities of rhaponticin and rhapontigenin

\begin{tabular}{|c|c|c|c|}
\hline Experimental model & Results obtained for rhaponticin or rhapontigenin & Results for reference compounds & References \\
\hline $\mathrm{PCA}$ reaction in mice & $\begin{array}{l}\text { Rhaponticin ( } 100 \mathrm{mg} / \mathrm{kg} \text { b.w., orally })-53 \pm 2 \% \text { of } \\
\text { PCA reaction inhibition } \\
\text { rhaponticin ( } 100 \mathrm{mg} / \mathrm{kg} \mathrm{b.w.,} \mathrm{intraperitoneally)-} \\
18 \pm 3 \% \text { of PCA reaction inhibition } \\
\text { Rhapontigenin ( } 25 \mathrm{mg} / \mathrm{kg} \text { b.w., intraperitoneally)- } \\
48 \pm 9 \% \text { of PCA reaction inhibition } \\
\text { Rhapontigenin ( } 50 \mathrm{mg} / \mathrm{kg} \text { b.w., intraperitoneally)- } \\
85 \pm 4 \% \text { of PCA reaction inhibition }\end{array}$ & $\begin{array}{l}\text { Disodium cromoglycate }(100 \mathrm{mg} / \mathrm{kg} \\
\text { b.w., administered orally)-38 } \pm 2 \% \\
\text { of PCA reaction inhibition }\end{array}$ & $\begin{array}{l}\text { Kim et al. } \\
\text { (2000) }\end{array}$ \\
\hline $\begin{array}{l}\text { Carrageenan-induced } \\
\text { acute edema in rats }\end{array}$ & $\begin{array}{l}\text { Rhapontigenin and rhaponticin ( } 50 \text { or } 100 \mathrm{mg} / \mathrm{kg} \text { ) } \\
\text { displayed the anti-edema effects }\end{array}$ & - & $\begin{array}{l}\text { Ko et al. } \\
(2004)\end{array}$ \\
\hline $\begin{array}{l}\text { Bleomycin-induced } \\
\text { pulmonary fibrosis in } \\
\text { mice }\end{array}$ & $\begin{array}{l}\text { Rhaponticin }(25,50 \text { or } 100 \mathrm{mg} / \mathrm{kg} / \text { day, } \\
\text { administered orally for } 14 \text { days }) \text {-decrease of } \\
\text { TGF- } \beta 1 \text {, IL- } 1 \beta \text {, IL- } 6 \text { and TNF- } \alpha \text { levels by about } \\
36,43,50 \text { and } 33 \% \text {, respectively }\end{array}$ & - & $\begin{array}{l}\text { Tao et al. } \\
\text { (2017) }\end{array}$ \\
\hline $\begin{array}{l}\text { Dextran sodium } \\
\text { sulfate-induced acute } \\
\text { colitis in mice }\end{array}$ & $\begin{array}{l}\text { Rhaponticin }(20,50 \text { or } 100 \mathrm{mg} / \mathrm{kg} \text {, administered by } \\
\text { gavage, for } 8 \text { days)-decrease of TNF- } \alpha \text {, IL- } 1 \beta \text {, } \\
\text { IL- } 6 \text {, IL- } 8 \text { levels by about } 38,32,33 \text { and } 70 \% \text {, } \\
\text { respectively; the level of IL-10 (anti- } \\
\text { inflammatory cytokine) was increased by about } \\
2.5 \text { fold }\end{array}$ & - & $\begin{array}{l}\text { Wei et al. } \\
\text { (2017) }\end{array}$ \\
\hline $\begin{array}{l}\text { Murine isoproterenol- } \\
\text { induced myocardial } \\
\text { infarction model }\end{array}$ & $\begin{array}{l}\text { Rhapontigenin }(1,2.5 \text { or } 5 \mathrm{mg} / \mathrm{kg} \text { b.w., for } \\
8 \text { days }) \text {-reduction of infarct size, the heart/body } \\
\text { weight index, creatinine kinase, lactate } \\
\text { dehydrogenase and cardiac troponin-T levels }\end{array}$ & - & Fan (2019) \\
\hline
\end{tabular}

studies (see de Sá Coutinho et al. 2018), the evaluation of pharmacological significance of rhaponticin and rhapontigenin remains mostly at the preliminary stage. In addition to their structural and chemical similarity, rhapontigenin and resveratrol also share some molecular mechanisms of their anti-inflammatory activity, at least in part; however, their physiological activities may be divergent.

The quick metabolism and low bioavailability of rhaponticin/rhapontigenin have hindered their experimental use and thus far prevented a full assessment of their properties; they have also limited current knowledge on their anti-inflammatory action. Nevertheless, several preliminary studies on new formulations of rhaponticin have been undertaken to increase its bioavailability. Therefore, detailed in vivo examinations are needed in order to more precisely elucidate the anti-inflammatory potential of rhaponticin and rhapontigenin, and to provide new data, which could allow for a more reliable evaluation of the pharmacological potential of these compounds.

Acknowledgements The work was supported by a Grant from University of Lodz, Poland (Dept. Gen. Biochem. 506/1136).

Open Access This article is distributed under the terms of the Creative Commons Attribution 4.0 International License (http:// creativecommons.org/licenses/by/4.0/), which permits unrestricted use, distribution, and reproduction in any medium, provided you give appropriate credit to the original author(s) and the source, provide a link to the Creative Commons license, and indicate if changes were made.

\section{References}

Aaviksaar A, Haga M, Kuzina K et al (2003) Hydroxystilbenes in the roots of Rheum rhaponticum. Proc Estonian Acad Sci Chem 52:99-107

Ahn K-S, Kim J-H, Oh S-R et al (2000) Inhibitory activity of stilbenes from medicinal plants on the expression of cell 
adhesion molecules on THP1 cells. Planta Med 66:641-644. https://doi.org/10.1055/s-2000-8634

Ashikawa K, Majumdar S, Banerjee S et al (2002) Piceatannol inhibits TNF-induced NF- $\kappa \mathrm{B}$ activation and NF- $\kappa \mathrm{B}-\mathrm{me}-$ diated gene expression through suppression of I $\mathrm{B} \alpha \alpha$ kinase and p65 phosphorylation. J Immunol 169:6490-6497. https://doi.org/10.4049/jimmunol.169.11.6490

Błaszczyk A, Sady S, Sielicka M (2019) The stilbene profile in edible berries. Phytochem Rev 18:37-67. https://doi.org/ 10.1007/s11101-018-9580-2

Cao H, Liu X, Ulrih NP et al (2019) Plasma protein binding of dietary polyphenols to human serum albumin: a high performance affinity chromatography approach. Food Chem 270:257-263. https://doi.org/10.1016/j.foodchem.2018. 07.111

Chang SC, Yang WV (2016) Hyperglycemia, tumorigenesis, and chronic inflammation. Crit Rev Oncol Hematol 108: 146-153. https://doi.org/10.1016/j.critrevonc.2016.11.003

Chen D, Liu JR, Cheng Y et al (2019) Metabolism of rhaponticin and activities of its metabolite, rhapontigenin: a review. Curr Med Chem. https://doi.org/10.2174/09298673266661 90121143252

Cheng CK, Luo JY, Lau CW et al (2019) Pharmacological basis and new insights of resveratrol action in the cardiovascular system. Br J Pharmacol. https://doi.org/10.1111/bph.14801

Czop M, Bogucka-Kocka A, Kubrak T et al (2019) Imaging flow cytometric analysis of stilbene-dependent apoptosis in drug resistant human leukemic cell lines. Molecules 24:1896. https://doi.org/10.3390/molecules24101896

de Sá Coutinho D, Pacheco MT, Frozza ML, Bernardi A (2018) Anti-inflammatory effects of resveratrol: mechanistic insights. Int J Mol Sci 19:1812. https://doi.org/10.3390/ ijms 19061812

El Khawand T, Courtois A, Valls J et al (2018) A review of dietary stilbenes: sources and bioavailability. Phytochem Rev 17:1007. https://doi.org/10.1007/s11101-018-9578-9

Eräsalo H, Hämäläinen M, Leppänen T et al (2018) Natural stilbenoids have anti-inflammatory properties in vivo and down-regulate the production of inflammatory mediators NO, IL6, and MCP1 possibly in a PI3K/Akt-dependent manner. J Nat Prod 81:1131-1142. https://doi.org/10.1021/ acs.jnatprod.7b00384

Etoh H, Yamashita N, Sakata K et al (1990) Stilbene glucosides isolated from Eucalyptus rubida, as repellents against the blue mussel mytilus edulis. Agric Biol Chem 54:2443-2444. https://doi.org/10.1271/bbb1961.54.2443

Fan Y (2019) Cardioprotective effect of rhapontigenin in isoproterenol-induced myocardial infarction in a rat model. Pharmacology 103:291-302. https://doi.org/10.1159/0004 96800

Fernández-Marín MI, Puertas B, Guerrero RF et al (2014) Preharvest methyl jasmonate and postharvest UVC treatments: increasing stilbenes in wine. J Food Sci 79:310-317. https:// doi.org/10.1111/1750-3841.12368

Gómez J, Simirgiotis MJ, Lima B et al (2019) Antioxidant, gastroprotective, cytotoxic activities and UHPLC PDA-Q orbitrap mass spectrometry identification of metabolites in Baccharis grisebachii decoction. Molecules 24:1085. https://doi.org/10.3390/molecules24061085

Goszcz K, Deakin SJ, Duthie GG et al (2015) Antioxidants in cardiovascular therapy: panacea or false hope? Front
Cardiovasc Med 2:29. https://doi.org/10.3389/fcvm.2015. 00029

He Y, Wang X, Suo Y, Ding C, Wang H (2016) Efficient protocol for isolation of rhaponticin and rhapontigenin with consecutive sample injection from fenugreek (Trigonella foenum-graecum L.) by HSCCC. J Chromatogr Sci 54:479-485. https://doi.org/10.1093/chromsci/bmv169

Hui Y, Li X, Chen X (2011) Assessment for the light-induced cis-trans isomerization of rhapontigenin and its glucoside rhaponticin by capillary electrophoresis and spectrometric methods. J Chromatogr A 1218:5858-5866. https://doi. org/10.1016/j.chroma.2011.06.100

Hurst WJ, Glinski JA, Miller KB, Apgar J, Davey MH, Stuart DA (2008) Survey of the trans-resveratrol and trans-piceid content of cocoa-containing and chocolate products. J Agric Food Chem 56:8374-8378. https://doi.org/10.1021/jf801297w

Kageura T, Matsuda H, Morikawa T et al (2001) Inhibitors from rhubarb on lipopolysaccharide-induced nitric oxide production in macrophages: structural requirements of stilbenes for the activity. Bioorg Med Chem 9:1887-1893. https://doi.org/10.1016/S0968-0896(01)00093-1

Kauppinen A, Suuronen T, Ojala J et al (2013) Antagonistic crosstalk between NF- $\kappa \mathrm{B}$ and SIRT1 in the regulation of inflammation and metabolic disorders. Cell Signal 25: 1939-1948. https://doi.org/10.1016/j.cellsig.2013.06.007

Kawakami S, Kinoshita Y, Maruki-Uchida H et al (2014) Piceatannol and its metabolite, isorhapontigenin, induce SIRT1 expression in THP-1 human monocytic cell line. Nutrients 6:4794-4804. https://doi.org/10.3390/nu6114794

Kim A, Ma JY (2018) Rhaponticin decreases the metastatic and angiogenic abilities of cancer cells via suppression of the HIF-1 $\alpha$ pathway. Int J Oncol 53:1160-1170. https://doi. org/10.3892/ijo.2018.4479

Kim D-H, Park E-K, Bae E, Han MJ (2000) Metabolism of rhaponticin and chrysophanol 8 -o- $\beta$-D-glucopyranoside from the rhizome of Rheum undulatum by human intestinal bacteria and their anti-allergic actions. Biol Pharm Bull 23:830-833. https://doi.org/10.1248/bpb.23.830

Ko S-K, Shin C-G, Lee H-S et al (2004) Effect of stilbene derivatives from Rheum undulatum on carrageenan-induced acute edema in rats. Korean J Pharmacogn 35:171-174

Kostadinović S, Wilkens A, Stefova M et al (2012) Stilbene levels and antioxidant activity of Vranec and Merlot wines from Macedonia: effect of variety and enological practices. Food Chem 135:3003-3009. https://doi.org/10.1016/j. foodchem.2012.06.118

Kutil Z, Kvasnicova M, Temml V et al (2015) Effect of dietary stilbenes on 5-lipoxygenase and cyclooxygenases activities in vitro. Int J Food Prop 18:471-1477. https://doi.org/10. 1080/10942912.2014.903416

Kwak HJ, Park SJ, Kim YN et al (2019) Optimization of extraction conditions for enhancing estrogenic activity of Rheum undulatum Linné using response surface methodology. Sep Sci Technol. https://doi.org/10.1080/01496395. 2019.1621342

Lee SW, Hwang BS, Kim MH et al (2012) Inhibition of LFA-1/ ICAM-1-mediated cell adhesion by stilbene derivatives from Rheum undulatum. Arch Pharm Res 35:1763-1770. https://doi.org/10.1007/s12272-012-1008-8

Lee D, Park S, Choi S et al (2018) In vitro estrogenic and breast cancer inhibitory activities of chemical constituents 
isolated from Rheum undulatum L. Molecules 23:1215. https://doi.org/10.3390/molecules23051215

Leopold JA (2015) Antioxidants and coronary artery disease: from pathophysiology to preventive therapy. Coron Artery Dis 26:176-183. https://doi.org/10.1097/MCA.000000000 0000187

Li G, Luan G, He Y et al (2018) Polyphenol stilbenes from fenugreek (Trigonella foenum-graecum L.) seeds improve insulin sensitivity and mitochondrial function in 3T3-L1 adipocytes. Oxid Med Cell Longev 2018:7634362. https:// doi.org/10.1155/2018/7634362

Liang X, Sun Y, Zeng W et al (2013) Synthesis and biological evaluation of a folate-targeted rhaponticin conjugate. Bioorg Med Chem 21:178-185. https://doi.org/10.1016/j. bmc.2012.10.044

Lim HJ, Cho EC, Shim J et al (2008) Polymer-associated liposomes as a novel delivery system for cyclodextrin-bound drugs. J Colloid Interface Sci 320:460-468. https://doi.org/ 10.1016/j.jcis.2008.01.025

Liu Y, Harinantenaina L, Brodie PJ et al (2013) Bioactive compounds from Stuhlmannia moavi from the Madagascar dry forest. Bioorg Med Chem 21:7591-7594. https://doi. org/10.1016/j.bmc.2013.10.038

Matsuda H, Kageura T, Morikawa T et al (2000) Effects of stilbene constituents from rhubarb on nitric oxide production in lipopolysaccharide-activated macrophages. Bioorg Med Chem Lett 10:323-327. https://doi.org/10.1016/ S0960-894X(99)00702-7

Matsuda H, Nakamura S, Yoshikawa M (2016) Degranulation inhibitors from medicinal plants in antigen-stimulated rat basophilic leukemia (RBL-2H3) cells. Chem Pharm Bull 64:96-103. https://doi.org/10.1248/cpb.c15-00781

McDougall GJ, Dobson P, Jordan-Mahy N (2010) Effect of different cooking regimes on rhubarb polyphenols. Food Chem 119:758-764. https://doi.org/10.1016/j.foodchem. 2009.07.030

Moriya J (2019) Critical roles of inflammation in atherosclerosis. J Cardiol 73:22-27. https://doi.org/10.1016/j.jjcc.2018. 05.010

Ngoc TM, Minh PT, Hung TM et al (2008) Lipoxygenase inhibitory constituents from rhubarb. Arch Pharm Res 31:598-605. https://doi.org/10.1007/s12272-001-1199-0

Nyemba AM, Ngando Mpondo T, Kimbu SF, Connolly JD (1995) Stilbene glycosides from Guibourtia tessmannii. Phytochemistry 39:895-898. https://doi.org/10.1016/ 0031-9422(94)00915-G

Oh S-R, Ryu SY, Park SH et al (1998) Anticomplementary activity of stilbenes from medicinal plants. Arch Pharm Res 1:703-706. https://doi.org/10.1007/BF02976761

Park EK, Choo MK, Yoon HK, Kim DH (2002) Antithrombotic and antiallergic activities of rhaponticin from Rhei Rhizoma are activated by human intestinal bacteria. Arch Pharm Res 25:528-533. https://doi.org/10.1007/BF02 976613

Park DH, Han JH, Jung YW et al (2016) Lipoxygenase inhibitory constituents from Rheum undulatum Linné. Planta Med 82:S1-S381. https://doi.org/10.1055/s-0036-1596837

Pashkow FJ (2011) Oxidative stress and inflammation in heart disease: Do antioxidants have a role in treatment and/or prevention? Int J Inflamm 2011:514623. https://doi.org/10. $4061 / 2011 / 514623$
Ramírez-Garza SL, Laveriano-Santos EP, Marhuenda-Muñoz $M$ et al (2018) Health effects of resveratrol: results from human intervention trials. Nutrients 10:1892. https://doi. org/10.3390/nu10121892

Roupe KA, Yáñez JA, Teng XW, Davies NM (2006) Pharmacokinetics of selected stilbenes: rhapontigenin, piceatannol and pinosylvin in rats. J Pharm Pharmacol 58:1443-1450. https://doi.org/10.1211/jpp.58.11.0004

Shin NH, Ryu SY, Lee H et al (1998) Inhibitory effects of hydroxystilbenes on cyclooxygenase from sheep seminal vesicles. Planta Med 64:283-284. https://doi.org/10.1055/ s-2006-957430

Smolarz HD, Hałka A, Chabros O, Dzido TH (2013) Rapid method for rhaponticin and deoxyrhaponticin separation and determination by TLC in Rheum rhaponticum L. and Rheum undulatum L. Acta Chromatogr 25:127-134. https://doi.org/10.1556/AChrom.25.2013.1.7

Sun Y, Zhao Y (2012) Enhanced pharmacokinetics and antitumor efficacy of PEGylated liposomal rhaponticin and plasma protein binding ability of rhaponticin. J Nanosci Nanotechnol 12:7677-7684. https://doi.org/10.1166/jnn. 2012.6599

Sun Y, Ji Z, Liang X et al (2012) Studies on the binding of rhaponticin with human serum albumin by molecular spectroscopy, modeling and equilibrium dialysis. Spectrochim Acta A Mol Biomol Spectrosc 87:171-178. https:// doi.org/10.1016/j.saa.2011.11.033

Sun Y, Zhao Y, Yang X (2013) A simple and rapid spectrofluorimetric method for determining the pharmacokinetics and metabolism of rhaponticin in rat plasma, feces and urine using a cerium probe. Luminescence 28:523-529. https://doi.org/10.1002/bio.2488

Sun Y, Wang W, Cheng H et al (2016) Study of the binding and energy transfer of erbium ion with rhaponticin and its pharmacokinetics application. Luminescence 31: 1251-1258. https://doi.org/10.1002/bio.3098

Sun Y, Liang X, Cheng H et al (2017) Review of characteristics, pharmacology, determination and pharmaco-kinetics of rhaponticin. Mini Rev Org Chem 14:24-34. https://doi.org/ 10.2174/1570193X13666161102152403

Tao L, Cao J, Wei W et al (2017) Protective role of rhapontin in experimental pulmonary fibrosis in vitro and in vivo. Int Immunopharmacol 47:38-46. https://doi.org/10.1016/j. intimp.2017.03.020

VanMen C, Jang YS, Zhu HM et al (2012) Chemical-based species classification of rhubarb using simultaneous determination of five bioactive substances by HPLC and LDA analysis. Phytochem Anal 23:359-364. https://doi. org/10.1002/pca.1365

Vincenzi S, Tomasi D, Gaiotti F et al (2013) Comparative study of the resveratrol content of twenty-one Italian red grape varieties. S Afr J Enol Vitic 34(2013):30-35. https://doi. org/10.21548/34-1-1078

Wang J, Liu M, Li X et al (2014) Anti-oxidative activities of ethanol extracts from both wild plant and suspension cell cultures of Rheum franzenbachii. Chin Herb Med 6:115-119. https://doi.org/10.1016/S1674-6384(14)60017-4

Wei W, Wang L, Zhou K et al (2017) Rhapontin ameliorates colonic epithelial dysfunction in experimental colitis through SIRT1 signaling. Int Immunopharmacol 42:185-194. https:// doi.org/10.1016/j.intimp.2016.11.024 
Wober J, Möller F, Richter T et al (2007) Activation of estrogen receptor-beta by a special extract of Rheum rhaponticum (ERr 731), its aglycones and structurally related compounds. J Steroid Biochem Mol Biol 107:191-201. https:// doi.org/10.1016/j.jsbmb.2007.04.002

Yamamoto T, Li Y, Hanafusa Y et al (2017) Piceatannol exhibits anti-inflammatory effects on macrophages interacting with adipocytes. Food Sci Nutr 5:76-85. https://doi.org/10. 1002/fsn3.366

Yao C, Narumiya S (2019) Prostaglandin-cytokine crosstalk in chronic inflammation. Br J Pharmacol 176:337-354. https://doi.org/10.1111/bph.14530

Yeh YH, Wang SW, Yeh YC et al (2016) Rhapontigenin inhibits TGF- $\beta$-mediated epithelial-mesenchymal transition via the $\mathrm{PI} 3 \mathrm{~K} / \mathrm{AKT} / \mathrm{mTOR}$ pathway and is not associated with HIF$1 \alpha$ degradation. Oncol Rep 35:2887-2895. https://doi.org/ 10.3892/or.2016.4664

Zhang R, Kang KA, Piao MJ et al (2007) Rhapontigenin from Rheum undulatum protects against oxidative-stress-induced cell damage through antioxidant activity. J Toxicol
Environ Health A 70:1155-1166. https://doi.org/10.1080/ 15287390701252766

Zhao Y, Wang L, Miao H et al (2011) LC method for the determination of rhaponticin in rat plasma, faeces and urine for application to pharmacokinetic studies. Chromatographia 73:599-603. https://doi.org/10.1007/s10337-011-1914-9

Zhao Y, Su Q, Cheng XL et al (2012) Pharmacokinetics, bioavailability and metabolism of rhaponticin in rat plasma by UHPLC-Q-TOF/MS and UHPLC-DAD-MSn. Bioanalysis 4:713-723. https://doi.org/10.4155/bio.12.24

Zhao XH, Han F, Li YL, Yue HL (2013) Preparative isolation and purification of three stilbene glycosides from the tibetan medicinal plant Rheum tanguticum maxim. ex Balf. by highspeed counter-current chromatography. Phytochem Anal 24:171-175. https://doi.org/10.1002/pca.2397

Publisher's Note Springer Nature remains neutral with regard to jurisdictional claims in published maps and institutional affiliations. 